\title{
Phytochemical analysis and antifungal activity of Costus lucanusianus J. Braun \& K. Schum aerial and rhizome crude extracts
}

\author{
Adesegun 0 Onanuga * and Ganiyat K Oloyede \\ Department of Chemistry, University of Ibadan, Ibadan, Nigeria.
}

GSC Biological and Pharmaceutical Sciences, 2022, 18(02), 215-223

Publication history: Received on 09 January 2022; revised on 12 February 2022; accepted on 14 February 2022

Article DOI: https://doi.org/10.30574/gscbps.2022.18.2.0068

\begin{abstract}
The phytochemical screening, and in vitro antifungal activity of the inflorescence, leaf, stem and rhizome crude extracts of Costus lucanusianus J. Braun \& K. Schum at concentrations 12.5-100 $\mu \mathrm{g} / \mathrm{mL}$ were determined against 4 fungal strains; Penicillium notatum, Candida albicans, Aspergillus niger and Rhizopus stolonifer by Agar well diffusion method. Secondary metabolites accountable for the activity observed are saponin, tannin, flavonoid, phlobatannins, reducing sugar, anthraquinones, phenol, alkaloid, resin, glycoside and terpenoids. Reducing sugar was present in all the extracts. The rhizome solvent extracts displayed the highest antifungal activity amongst the organs extracts. The inflorescence, stem and rhizome aqueous extracts displayed no activity at all concentrations.

In this present study, the antifungal activity of Costus lucanusianus J. Braun \& K.Schum aerial and rhizome extracts is reported. The activity shown by the plant organs justifies the use of the plant in the treatment of urinary tract infection and venereal diseases in ethnomedicine, and its usefulness in the preservation of food crops.
\end{abstract}

Keywords: Phytochemicals; Antifungal activity; Venereal diseases; Costus lucanusianus J. Braun \& K. Schum

\section{Introduction}

Medicinal plants serves as an alternative therapy to antibiotics for many pathogenic microorganisms [1]. This is because they contain some important organic compounds (secondary metabolites), like carbohydrates, tannins, alkaloids, terpenes, flavonoids and steroids, which under in vitro conditions, are responsible for anti-microbial activities [2]. Medicinal plants and their herbal products usages in emerging countries, particularly in tropical Africa for curing ailments are still in practice [3][4].

Costus lucanusianus J. Braun \& K. Schum (Costaceae) is an evergreen, perennial, rhizomatous, herbaceous and aromatic plant species with a thin stem that grows nearly vertically. The mature height of the plant is about 6-8 feet [5]. The bracts on the cone structure are open. Each bract covers one flower. The individual flowers are 1-1.5 inches across. Each has a thin, tissue-like texture. The stem grows about seven feet tall before it throws out a terminal inflorescence.

Inflorescence infusion of $C$. lucanusianus is used as a remedy for tachycardia and stomach problem. The leaf sap which is acidic is used in the treatment of eye problem and headache. The sap from the stem is used as a remedy for venereal diseases, urinary tract infection, urethral discharge, jaundice, miscarriage prevention and in Gabon, as an eye drop to control filariasis. The stem is also chewed to cure cough [5]. The ingestion of the rhizome decoction is also useful in the treatment of venereal, diarrhea, malaria and leprosy diseases [6]. It is extensively used in tropical Africa as a medicinal plant. The leaves have also been reported to be useful in the preservation of bitter kola. Pharmacological activities such as anti-inflammatory, antidiarrheal of the leaf aqueous extract [7], renoprotective, hepaprotective and

\footnotetext{
${ }^{*}$ Corresponding author: Adesegun 0 Onanuga

Department of Chemistry, University of Ibadan, Ibadan, Nigeria.

Copyright $(2022$ Author(s) retain the copyright of this article. This article is published under the terms of the Creative Commons Attribution Liscense 4.0.
} 
antihyperglycemic of the leaf aqueous extract [8], tocolytic activity [9] have been reported. Nevertheless, little is known about its pharmacological activities and chemical components [8].

As a result of the medicinal importance of $C$. lucanusianus in the treatment of urinary tract infection and venereal disease, and its application in the preservation of food crops, this research is aimed to examine the phytochemical constituents and antifungal property of $C$. lucanusianus aerial and rhizome extracts.

\section{Material and methods}

\subsection{Plant materials}

Samples of inflorescence, leaf, rhizome and stem of $C$. lucanusianus were obtained fresh from Akobo Ibadan, Oyo state, South-west, Nigeria (at a geographical coordinate of 70 25! 45.4” N 35 56! 10.9” E; altitude $830 \mathrm{ft}$.) on $14^{\text {th }}$ October 2015. The taxonomic identification of the plant materials was confirmed by a senior plant taxonomist, Mr L.T Soyewo of Forestry Research Institute of Nigeria (FRIN) herbarium, Ibadan. Voucher specimens (FH110048) were deposited at the FRIN herbarium.

\subsection{Extraction of crude extracts}

The collected inflorescence, leaf, stem and rhizome were washed thoroughly with water to remove soil particles, cut into pieces, air-dried for two weeks separately under shade. These were ground separately and kept in airtight containers until use.

Coarse inflorescence, leaf, stem and rhizome (50 g) each were cold macerated successively with hexane, ethyl acetate and methanol ( $200 \mathrm{~mL}$ each) for 72 hours. Extraction of each sample (50 g) with distilled water was also carried out separately for 48 hours. The filtration of the extracts was with Whatmann filter paper using Buchner funnel. Concentration of the filterates obtained was subsequently carried out by the use of rotary evaporator at $40^{\circ} \mathrm{C}$ under reduced pressure [2]. These extracts were put in a desiccator over anhydrous sodium sulphate until use. The weights and percentage yields $(\mathrm{w} / \mathrm{w})$ of the extracts were determined.

\subsection{Qualitative Phytochemical Screening}

The individual extracts were phytochemically screened qualitatively in order to determining the existence of secondary metabolites like tannins, alkaloids, flavonoid, saponin, triterpenes, resin, glycosides, reducing sugar, anthraquinone, phlobatannin and phenols using standard methods [10][11]. Stock solutions of each of the crude extracts were prepared by dissolving extracts $(1 \mathrm{mg})$ in $10 \mathrm{~mL}$ of the individual mother solvents. The stock solutions obtained were subjected to phytochemical screening.

\subsection{Antifungal activity}

\subsubsection{Microbial Cultures}

Clinical strains of Candida albicans, and non-human pathogenic strains of Penicillium notatum, Aspergillus niger and Rhizopus stolonifer were supplied by the Pharmaceutical Microbiology Laboratory and Veterinary Medical Microbiology, University of Ibadan. Stock solution of each extract was prepared by dissolving $1 \mathrm{mg}$ in $10 \mathrm{~mL}$ of their respective solvents to obtain a final concentration of $100 \mu \mathrm{g} / \mathrm{mL}$. Four different concentrations of the stock solutions $(12.5 \mu \mathrm{g} / \mathrm{mL}-100$ $\mu \mathrm{g} / \mathrm{mL}$ ) were obtained by double-fold serial dilution.

\subsubsection{Antifungal assay: Preparation of inoculum}

Fungal strains taken from the stock were subcultured on to Sabour and dextrose agar (SDA). The mixture was incubated at $35^{\circ} \mathrm{C}$ for three days. The yeast spores obtained were suspended in sterile distilled water (5 mL) to obtain $10^{5} \mathrm{cells} / \mathrm{mL}$. Dilution of the organisms to 1:100 was carried out and $0.2 \mathrm{~mL}$ of 1:100 dilution of the adjusted inoculum was taken and spread over the agar using a sterile spreader [12].

\subsubsection{Surface plate method}

The prepared sterile (SDA) (62 g/L) was left to solidify for 45 minutes in sterile plates in triplicate. The antifungal activity of the extracts was determined by using $30 \mu \mathrm{L}$ of the each concentration $(12.5 \mu \mathrm{g} / \mathrm{mL}-100 \mu \mathrm{g} / \mathrm{mL})$. The experiment was performed in triplicate on (SDA) impregnated with fungal strains. Wells were made inside the set plates using $8 \mathrm{~mm}$ diameter sterile cork borer. Different concentrations of the extracts, and the controls (tioconazole $70 \%$ ) 
and mother liquor were poured into the wells and there was perfect diffusion into the agar for 120 minutes. Thereafter, the incubation of the plates uprightly for 48 hours at $28^{\circ} \mathrm{C}$ took place. The inhibition zone diameter (IZD) in mm was measured [13].

\subsection{Statistical Analysis}

All data were subjected to statistical analysis which was determined by making use of one way ANOVA. The differences between the data were considered significant at $\mathrm{P} \leq 0.05$.

\section{Results and discussion}

Extracts yields (\%) are presented in Table 1. The percentage extractive value of leaf hexane extract was the highest followed by the rhizome methanol extract. These low yields recorded in this present work corroborate the low yields reported for the extracts obtained from Costus genus [14][15].

Table 1 The colour and percentage yields of 16 extracts of Costus lucanusianus J. Braun \& K. Schum

\begin{tabular}{|c|c|c|c|}
\hline Extraction solvents & Plant materials & Colours & \% Yields \\
\hline \multirow[t]{4}{*}{ Hexane } & Inflorescence & Brown & 0.20 \\
\hline & Leaf & Greenish black & 3.00 \\
\hline & Stem & Light green & 0.80 \\
\hline & Rhizome & Light brown & 0.21 \\
\hline \multirow[t]{4}{*}{ Ethyl acetate } & Inflorescence & Brown & 0.04 \\
\hline & Leaf & Greenish black & 1.12 \\
\hline & Stem & Light green & 0.15 \\
\hline & Rhizome & Light brown & 0.07 \\
\hline \multirow[t]{4}{*}{ Methanol } & Inflorescence & Dark brown & 0.57 \\
\hline & Leaf & Dark brown & 0.65 \\
\hline & Stem & Brown & 0.08 \\
\hline & Rhizome & Dark brown & 1.20 \\
\hline \multirow[t]{4}{*}{ Aqueous } & Inflorescence & Dark brown & 0.50 \\
\hline & Leaf & Dark brown & 1.10 \\
\hline & Stem & Brown & 0.06 \\
\hline & Rhizome & Dark brown & 1.02 \\
\hline
\end{tabular}

\subsection{The phytochemical analyses results of $C$. Iucanusianus solvent extracts are presented in Table 2.}

Phytochemical screening of bioactive components of the inflorescence and rhizome of $C$. lucanusianus are reported for the first time.

The phytochemical screening results showed that $C$. lucanusianus is rich in phytochemicals amongst which were alkaloids, terpenoids, saponin etc (Table 2). The inflorescence methanol extract contained phlobatannin while anthraquinone was detected in the ethyl acetate. It was observed that the entire extracts obtained from the plant four organs contained reducing sugar.

Saponins, phlobatannin, reducing sugars, alkaloids and glycosides are present in all the aqueous extracts. 
Table 2 Phytochemical analyses results of $C$. lucanusianus crude extracts

\begin{tabular}{|c|c|c|c|c|c|c|c|c|c|c|c|c|c|c|c|c|}
\hline & Aqueous & Hexane & $\begin{array}{l}\text { Ethyl } \\
\text { acetate }\end{array}$ & Methanol & Aqueous & Hexane & $\begin{array}{l}\text { Ethyl } \\
\text { acetate }\end{array}$ & Methanol & Aqueous & Hexane & $\begin{array}{l}\text { Ethyl } \\
\text { acetate }\end{array}$ & Methanol & Aqueous & Hexane & $\begin{array}{l}\text { Ethyl } \\
\text { acetate }\end{array}$ & Methanol \\
\hline $\begin{array}{l}\text { Bioactive } \\
\text { Components }\end{array}$ & \multicolumn{4}{|c|}{ Inflorescence } & \multicolumn{4}{|c|}{ Leaf } & \multicolumn{4}{|c|}{ Stem } & \multicolumn{4}{|c|}{ Rhizome } \\
\hline Saponin & + & - & + & + & + & + & + & + & + & - & + & + & + & + & - & + \\
\hline Tannin & + & + & - & + & + & - & - & + & - & - & + & + & - & - & + & + \\
\hline Flavonoids & - & - & + & - & - & - & + & - & - & - & + & + & - & - & - & + \\
\hline Phlobatannis & + & - & - & + & + & - & - & - & + & - & - & - & + & - & - & - \\
\hline Reducing sugar & + & + & + & + & + & + & + & + & + & + & + & + & + & + & + & + \\
\hline Anthraquinones & - & - & + & - & - & - & - & - & - & - & - & - & - & - & - & - \\
\hline Phenol & + & - & - & + & + & - & - & + & - & - & - & - & - & - & - & - \\
\hline Alkaloids & + & + & - & - & + & - & + & + & + & + & - & - & + & + & - & + \\
\hline Resin & + & + & + & + & + & - & + & + & + & - & + & + & + & + & - & + \\
\hline Glycosides & + & + & - & + & + & + & + & + & + & + & + & + & + & - & + & + \\
\hline Terpenoids & + & - & - & + & - & - & + & + & - & - & + & + & + & + & + & - \\
\hline
\end{tabular}


Table 3A Antifungal activity results of crude extracts

\begin{tabular}{|c|c|c|c|c|c|c|c|c|c|}
\hline \multirow{2}{*}{ Parts of plant used } & \multirow{2}{*}{$\begin{array}{c}\text { Solvent extracts } \\
\text { Concentration } \\
(\mu \mathrm{g} / \mathrm{mL})\end{array}$} & \multicolumn{4}{|c|}{ C. albicans } & \multicolumn{4}{|c|}{ A. niger } \\
\hline & & 100 & 50 & 25 & 12.5 & 100 & 50 & 25 & 12.5 \\
\hline \multirow[t]{4}{*}{ Inflorescence } & Aqueous & - & - & - & - & - & & - & - \\
\hline & Hexane & $15.3 \pm 1.067$ & $13.3 \pm 1.067$ & 10 & - & $14.7 \pm 1.067$ & $12.7 \pm 1.067$ & 10 & - \\
\hline & Ethyl acetate & $15.3 \pm 1.067$ & $12.7 \pm 1.067$ & 10 & - & $17.3 \pm 1067$ & $14.7 \pm 1.067$ & 12 & 10 \\
\hline & Methanol & $13.3 \pm 1.067$ & 10 & - & - & $13.3 \pm 1.067$ & 10 & - & - \\
\hline \multirow[t]{5}{*}{ Leaf } & Aqueous & $18.7 \pm 1.067$ & $16.7 \pm 1.067$ & 14 & 12 & $17.3 \pm 1.067$ & 14 & 12 & 10 \\
\hline & Hexane & - & - & - & - & - & - & - & - \\
\hline & Ethyl acetate & $17.3 \pm 1.067$ & $14.7 \pm 1.067$ & $12.7+1.067$ & 10 & $16.7 \pm 1.067$ & 14 & 12 & 10 \\
\hline & Methanol & 16 & 14 & 12 & 10 & $18 \pm 1.848$ & $15.3 \pm 1.067$ & $13.3 \pm 1.067$ & 10 \\
\hline & Aqueous & - & - & - & - & - & - & - & - \\
\hline \multirow[t]{4}{*}{ Stem } & Hexane & $14.7 \pm 1.067$ & $13.3 \pm 1.06$ & 10 & & $14.7 \pm 1.067$ & 12 & 10 & \\
\hline & Ethyl acetate & $20 \pm 0.533$ & $18.7 \pm 1.067$ & 16 & 14 & $18.7 \pm 1.067$ & $16.7 \pm 1.067$ & 14 & 12 \\
\hline & Methanol & $15.33 \pm 1.067$ & $13-3 \pm 1.067$ & 10 & - & $15.33 \pm 1.067$ & 12 & 10 & - \\
\hline & Aqueous & - & - & - & - & - & - & - & - \\
\hline \multirow[t]{4}{*}{ Rhizome } & Hexane & $18.7 \pm 1.067$ & $16.7 \pm 1.067$ & 15 & 14 & $19.3 \pm 1.067$ & $17.3 \pm 1.067$ & $15.3 \pm 1.067$ & $13.3 \pm 1.067$ \\
\hline & Ethyl acetate & $17.3 \pm 1.067$ & $14.7 \pm 1.067$ & 12 & 10 & $17.3 \pm 1.067$ & $15.3 \pm 1.067$ & $12.7 \pm 1.067$ & 10 \\
\hline & Methanol & $18.7 \pm 1.067$ & $17.3 \pm 1.067$ & $14.7 \pm 1.067$ & 12 & $17.3 \pm 1.067$ & 14 & 12 & 10 \\
\hline & $\begin{array}{c}\text { +ve standard } \\
\text { Tiocanazole } 70 \%\end{array}$ & & & 28 & & 26 & & & \\
\hline
\end{tabular}


Table 3B Antifungal activity results of crude extracts

\begin{tabular}{|c|c|c|c|c|c|c|c|c|c|}
\hline \multirow[t]{2}{*}{ Parts of plant used } & \multirow{2}{*}{\begin{tabular}{|c|} 
Solvent extracts \\
Concentration \\
$(\mu \mathrm{g} / \mathrm{mL})$ \\
\end{tabular}} & \multicolumn{4}{|c|}{ P. notatum } & \multicolumn{4}{|c|}{ R. stolonifer } \\
\hline & & 100 & 50 & 25 & 12.5 & 100 & 50 & 25 & 12.5 \\
\hline \multirow{3}{*}{ Inflorescence } & Hexane & - & - & - & - & - & - & & - \\
\hline & Ethyl acetate & $15.3 \pm 1.067$ & $12 \pm 1.067$ & 10 & - & 14 & 12 & 10 & \\
\hline & Methanol & $15.3 \pm 1.067$ & $13.3 \pm 1.067$ & 10 & - & $14.7 \pm 1.067$ & 12 & 10 & \\
\hline \multirow[t]{5}{*}{ Leaf } & Aqueous & - & - & - & - & - & - & - & \\
\hline & Hexane & - & - & - & - & - & - & - & \\
\hline & Ethyl acetate & $14.7 \pm 1.067$ & 12 & 10 & - & 14 & 12 & 10 & \\
\hline & Methanol & 14 & 12 & 10 & - & $16.7 \pm 1.067$ & 14 & 10 & 10 \\
\hline & Aqueous & - & - & - & - & - & & & \\
\hline \multirow[t]{3}{*}{ Stem } & Hexane & & & & & & & & \\
\hline & Methanol & - & - & - & - & - & & & \\
\hline & Aqueous & - & - & - & - & - & & & \\
\hline \multirow[t]{5}{*}{ Rhizome } & Hexane & & & & & & & & \\
\hline & Ethyl acetate & $19.0 \pm 0.924$ & $17.3 \pm 0.533$ & $15.0 \pm 0.924$ & $12.7 \pm 1.067$ & $18.7 \pm 1.067$ & $17.0+0.924$ & $15.0+0.924$ & 10 \\
\hline & Methanol & $19.3 \pm 1.067$ & $17.3 \pm 1.067$ & 14 & 12 & $17.3 \pm 1.067$ & $14.7+1.067$ & 12 & $12.7+1.067$ \\
\hline & & $16.7 \pm 1.067$ & 14 & 12 & 10 & $16.7+1.067$ & & $14.7+1.067$ & \\
\hline & $\begin{array}{c}\text { +ve standard } \\
\text { Tiocanazole70\% }\end{array}$ & 28 & & & & 28 & & & \\
\hline
\end{tabular}


In this present study, the presence of saponin and absence of alkaloid in the stem methanol extract are reported. However, the existence of alkaloid and absence of saponins was recorded by [16]. Likewise, the present result of the leaf aqueous extract revealed the presence of alkaloids. However, the absence of alkaloids was reported by [15].

Climatic conditions, physiological state and geographical localization of the plants are part of the reasons that might be responsible for the varying chemical composition [17].

\subsection{Antifungal activity}

The antifungal activity results are shown in Table 3.

Rhizome organic solvent extracts showed activity against all the tested organisms at all concentrations while the leaf hexane extract was inactive against the four tested fungal. The leaf aqueous extract showed activity only against $C$. albicans $(12.0 \mathrm{~mm})$ and $A$. niger $(10.0 \mathrm{~mm})$ at the minimum concentration of $25 \mu \mathrm{g} / \mathrm{mL}$ while the aqueous extracts of the inflorescence, stem and rhizome organs displayed no antifungal activity against the tested fungal strains.

Amongst the 4 organs organic solvent extracts, the rhizome extracts displayed the highest antifungal activity especially against $C$. albicans. Statistically, there is no significant difference noticed between the activity of the various organic extracts of the rhizome organ.

The antimicrobial inactivity of $C$. speciosus rhizome methanol and aqueous extracts against E. coli, $S$. aureus, $K$. pneumonia and P. aeruginosa was documented by [18][19]. According to [18], C. speciosus rhizome hexane extract among others tested at $12.5 \mathrm{mg} / \mathrm{mL}$ displayed the highest antimicrobial property only against B. subtilis (12 mm) and $S$. aureus $(15 \mathrm{~mm})$, also the promising antifungal property of $C$. speciosus rhizome ethyl acetate fraction against $A$. niger and C. albicans was reported by [20].

The inflorescence, leaf and stem hexane extracts and the stem methanol extract of $C$. lucanusianus are resistant to $R$. stolonifer and P. notatum. The inactivity exhibited by the inflorescence, rhizome and stem aqueous extracts against all tested fungal may be because the active components are present in an inadequate amount in the concentrations of the extracts to be able to display activity [21]. Activity against other fungal strains not utilised in this present work may be shown by the extracts [22]. The antifungal activity shown by the plant extracts against Penicillium notatum, Aspergillus niger and Rhizopus stolonifer corroborates the usage of the plant in the preservation of bitter kola [23].

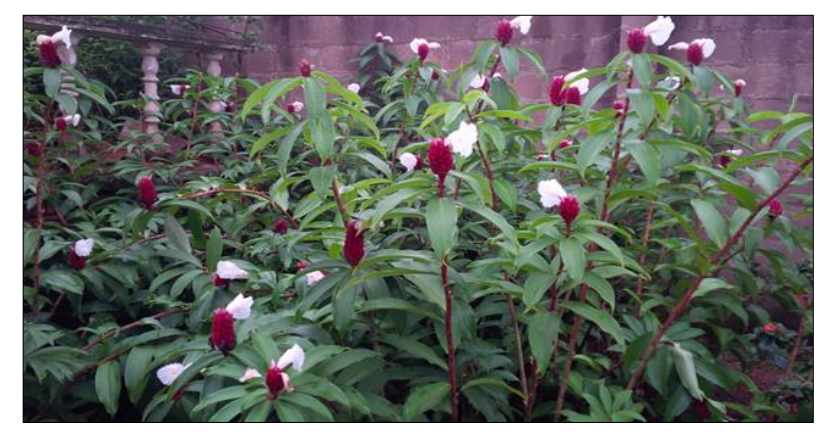

Figure 1 Matured plant of Costus lucanusianus

Photograph was taken in June 2016 at natural habitat, Akobo area, Ibadan North Local Government of Oyo State.

\section{Conclusion}

In this present study, the results of the phytochemical screenings of the extracts revealed the presence of an array of bioactive components. C. lucanusianus rhizome solvent extracts amongst other organs extracts displayed the highest activity against tested organisms. There was no antifungal activity displayed by the inflorescence, stem and rhizome aqueous extracts of $C$. lucanusianus. The antifungal property of inflorescence, leaf, stem and rhizome solvent extracts of C. lucanusianus against $C$. albicans could thereby justify the use of the plant in traditional medicine in the treatment of urinary tract infection and venereal diseases. Likewisely, the other activity shown against the non-human pathogens also supported the use of the plant in the preservation of food crops locally. 


\section{Compliance with ethical standards}

\section{Acknowledgments}

Authors are grateful to Mr Soyewo L.T of Forestry Research Institute of Nigeria, Ibadan for the identification of the plant

\section{Disclosure of conflict of interest}

The authors declares that there is no competing interest.

\section{Statement of informed consent}

The authors give their consent for the publication.

\section{References}

[1] Kala CP, Dhyani PP, Sajwan BS. Developing the medicinal plants sector in northern India: challenges and opportunities. J. Ethnobiol Ethnomed. 2006; 2: 32-37.

[2] Cowan MM. Plant products as antimicrobial agents. Clin Microbiol Rev. 1999; 12(4): 564-582.

[3] Akinyemi KO, Oluwa OK, Omomigbehin EO. Antimicrobial activity of crude extracts of three medicinal plants used in South-Western Nigeria folk medicine on some Food borne bacterial pathogens. Afr J. Tradit. Complem. Alternat Med. 2006; 3:13-22.

[4] Okpuzorl J, Oloyede AM. Anti-inflammatory, anti-pyretic and anti-diarrhoeal properties of an anti-haemorrhoid Tri-herbal pill. Nature and science. 2009; 7(8): 89-94.

[5] Burkill HM. Costus lucanusianus. The Useful Plants of West Tropical Africa. 1985; 1: 520.

[6] Lambert N, Baccou JC, Sauvalre Y. Screening of diosgenin in rhizome from 3 Costus species (C.deistellii, C.igneus, C.lucanusianus). Planta Medica. 1988; 54(4): 366-367.

[7] Owolabi OJ, Nworgu ZAM. Anti-inflammatory and anti-nociceptive activities of Costus lucanusianus (Costaceae). Pharmacol. Online. 2009; 1: 1230-1238.

[8] Saliu JA, Fapohunda O. The antihyperglycemic, hepatoprotective and renoprotective potentials of the aqueous extract of Costus lucanusianus on streptozotocin-induced diabetic rats. J. Appl. Life Sci. Intern. 2016; 4(2): 1-10.

[9] Foungbe S, Sawadogo D, Deame C. Experimental study of the uterorelaxant activity of Alstonia boonei (Apocynacces) and Costus lucanusianus (zingiberaccees) traditionally used in Ivory Coast as anti-abortion agents. French Pharmaceutical Annals. 1987; 45: 373-377.

[10] Trease GE, Evans WC. Pharmacognosy. Baillier Tindall. London. UK, 13th Edition. 1989.

[11] Sofowora A. Screening plants for bioactive agents in medicinal plants and traditional medicine in Africa. Spectrum books limited Ibadan, Nigeria. 2nd edition. 1993; 97-145.

[12] Aberkane A, Cuenca-Estrella M, Gomez-Lopez A, Petrikkou E, Mellado E, Monzon A, Rodriguez-Tudela JL. Comparative evaluation of two different methods of inoculum preparation for antifungal susceptibility testing of filamentous fungi. J. Antimicrob Chemother. 2002; 50(5): 719-722.

[13] Perez C, Paul M, Bazerque P. Antibiotic assay by Agar well diffusion method. Acta Biol Med Experimt. 1990; 15: 113-115.

[14] Shiny T. Phytochemical investigation of the insulin plant 'Costus pictus' D.Don. Int.J. Res. Pharma. Biomed. Sci. 2013; 4(2): 97-104.

[15] Owolabi OJ, Omogbai EKI, Oduru EE. Antidiarrheal evaluation of the aqueous leaves extracts of Costus lucanusianus. J. Appl Sci Res. 2007; 3(12): 2052-2055.

[16] Traore AN, Sigidi MT, Boukandou MM, Ntlhamu NT, Musoliwa R, Tshisikhawe, Potgieter N. Anti-microbial and immune modulatory properties of indigenous plants found in Central and Southern Africa. Antimicrobial research: Novel bioknowlege and Educational Programs (A. Mendez-vilas, Ed). 2017.

[17] Dinan L, Harmatha J, Lafont R. Review on Chromatographic procedures for the isolation of plant steroids. J Chromatography A. 2007; 935:105-123. 
[18] Duraipandiayn V, Al- Harbi NA, Ignacimuthu S, Muthukumar C. Antimicrobial activity of sesquiterpene lactones isolated from traditional medicinal plant, Costus speciosus. BMC Complem Altern Med. 2012; 12(13): 1-6.

[19] Saraf A. Phytochemical and antimicrobial studies of medicinal plants Costus speciosus (Koen). E-Journal of Chemistry. 2010; 7(1): 405-413.

[20] Duraipandiyan V, Ignacimuthu S. Antifungal activity of traditional medicinal plants from Tamil Nadu, India. Asian Pacific J Tropical Biomed. 2011; 2(25): 1-7.

[21] Taylor JLS, Rabe T, McGraw LJ, Jager AK, Van Staden J. Towards the scientific validation of traditional medicinal plants. Plant Growth Regulation. 2001; 34(1): 23-37.

[22] Shale TL, Strik WA, Van Staden J. Screening of plants used by Southern African traditional healers in the treatment of dysmenorrhoea for prostaglandin-synthesis inhibitors and uterine relaxing activity. J Ethnopharmacol. 1999; 64: 9-14.

[23] Kayode J, Ige OE, Ojo BM. Botanicals used in the storage of farm produce in Ondo State, Nigeria. Ethnobot. leafl. 2009; 13:603-610. 